\title{
Digitalization of Street Hawker and Vendor Services
}

\author{
Shubham Aggarwal, Anubhav Bose, Ritu Gupta
}

\begin{abstract}
Since the marketplace is far from the residential colonies, people prefer to buy goods from street hawkers and local vendors due to easy availability. However due to absence of any proper system, there are problems faced by the customers, hawkers as well as the general public. There are several problems that are caused by Street hawkers and vendors in terms of traffic jams and occupying public spaces such as footpaths, pavements, etc. Improper way of disposing food waste and garbage by hawkers is another issue. They cause congestion on the roads. However, the vendors and hawkers also face a lot of problems and are harassed by the customers and the city authorities such as The Municipal Corporation, Police, etc. which leads to exploitation and extortion. They also have a right to earn their livelihood in a respectable manner. In order to resolve this problem, we intend to develop an android application 'Vendiz' which will lead to a proper digital system and interaction between customers and the street hawkers and vendors and help the customers to navigate through the available items at different vendors via the application.
\end{abstract}

Index Terms: street hawkers, vendors, customers, digitalization, application.

\section{INTRODUCTION}

Vendors provide a wide array of services, goods and commodities to the urban population at reasonable prices and convenient locations. We daily need fruits and vegetables and other household commodities for use. We also require fish, meat, snacks and other goods. We may also occasionally require flowers and readymade garments. Vendors nearly sell 300 types of eatables and other goods to the public. Middle and lower class consumers specifically prefer to buy goods from these local street vendors. This indicates a huge amount of demand and therefore we can see a high number of hawkers and local vendors out on the roads in order to earn livelihood. The average age of vendors is found out to be between 16-40 years which indicate that it requires enormous physical labor. There are several problems that are caused by Street hawkers and vendors in terms of traffic jams and occupying public spaces such as footpaths, pavements, etc. Improper way of disposing food waste and garbage by hawkers is another issue. They cause congestion on the roads. However, the vendors and hawkers also face a lot of problems and are harassed by the customers and the city authorities such as The Municipal Corporation, Police, etc. which leads to exploitation and extortion.

\section{Problems:}

Caused to street hawkers and vendors.

Revised Manuscript Received on July 22, 2019

Shubham Aggarwal, Amity University, Noida, UP, India.

Anubhav Bose, Amity University, Noida, UP, India.

Ritu Gupta, Amity University, Noida, UP, India.

- Hawkers are on the move from one place to another irrespective of the heat, wind, rain and cold.

- Calling out loud to attract buyers requires time and energy.

- Vendors are regularly subjected to mental and physical pressure by city officials.

- There are no separate places allocated for street hawkers or local vendors.

- Vendors have to deal with the authorities such as Police and the municipal corporation.

\section{Caused by street hawkers and vendors.}

- The major problem caused is traffic jams and congestion on streets and pavements.

- Hawkers occupy public spaces like footpaths, pavements, streets, etc.

- Health issues due to unhygienic food sometimes.

- Improper way of disposing waste causing garbage and pollution.

- Congestion on roads causes noise pollution.

- Items required by customers are not always available.

In this paper, we will be discussing the existing vending system and the need to digitalize it into an application platform, also a brief description of our proposed android application is discussed. The background section of the paper will highlight the significance of street vendors in Indian economy and need to improve vending system. The literature review section would provide the readers about various statistical data and recent researches done in this field. We will be discussing about the application proposed to digitalize the vending system in Proposed Application section and will be comparing various application available on play store.

\section{LITERATURE REVIEW}

The work force in India is dominated by the informal sector that constitutes $86 \%$ of the total work force and the informal economy makes up for $93 \%$ of the economy. Street vending falls under informal sector, which in India is growing more rapidly in comparison to the formal sector. It has been a significant means of generating income and is considered a good means of employment for the urban poor population as it needs no or little skills with a lesser financial inputs. Moreover, these vendors see vending as a means with which they can provide for themselves and their family's survival. They move to urban areas in search of better occupation to provide for their needs in alternative to farming in rural areas. [1] 


\section{Street Vendors in India}

As per the National Policy for Street Vendors, in our country, around $2.5 \%$ of the population in urban areas are street vendors and hawkers. So around one crore urban population is involved in this occupation. And on each vendor there are three to four dependents, that means around five crore people in urban India are dependent on this occupation for their livelihood and survival. The heavy dependence on this occupation is the result of fast urbanization (and the services it provides to the urban residents), unemployment and poverty which they have to overcome themselves [2]. On an average the daily turnover of a vendor per day is Rs 1000 approx. which means the total turnover is approx. Rs 1000 crore per day. So it can be considered as an important source of earning livelihood for the poor in India. However, the wage earned by this significant section of the society is not enough to provide them basic amenities of life as about 269 million people were living below the poverty line in 2011-12 as per the Tendulkar Committee report. Unemployment rate as estimated by the Ministry of Labour was 3.8\% in 2011-12. Therefore, it is the duty of those in positions of power to accommodate the needs of poor people and devise policies to provide more opportunities of employment and better remuneration for their labour. By indulging in vending business, the poor are contributing to the economy in their own little way. Even the Supreme Court recognizes their occupation as a service to the society and has granted them the right to continue their work from the street. Therefore, the government along with the police forces should ensure the smooth functioning of their activities so that it does not come in the way of traffic or create other issues which we have discussed previously.

Vendors provide a variety of goods to the local public at reasonable rates. This include selling of fruits, vegetables, fast foods, clothes, electronics, utensils, leather and plastic goods, flowers etc. Vendors doesn't sell their goods from one permanent place, it is found that most of the vendors travel within $5 \mathrm{~km}$ of their work origin. Thus the average time spent by vendors on vending is between 8-10 hours per day. Working for longer hours would make more income for them. Research shows that around 56 per cent of the street vendors in India earns more than Rs. 150 per day and around 17 per cent earns up to Rs. 100 only and rest between Rs. 100-150.

\section{Vendors Profile}

Various researches and articles shows that majority of the street vendors are in age group of between 22-52 years which is considered to be a productive age group. The literacy level of street vendors is found to be comparatively low than other business competitors of retail sector. But despite being illiterate they manage to run their business very efficiently. The data of top ten cities shows that majority of the street vendors belong to Hindu religion (over 70\%). Mainly two form of vending activities are practiced, mobile accessories and stationary. Mobile vendors sell their goods while travelling and carry their goods on push carts, while Stationary vendors occupy a space at roadsides, pavements or footpaths, taking up space of pedestrians, thus causing congestion and usual traffic jams. Thus, controlling them and managing the city environment has become difficult for the municipal corporations. This includes managing footpath, controlling of increasing vending activities and providing easy movement to the pedestrians. [3]
Even though the informal sector turns out to be a significant system for financial development and improvement in the economy, Studies showed that in most of the less developed countries like the countries in Asia, there is no legal status for street vendor to conduct their business and they suffer harassment constantly by the state authorities. Corruption, in the form of bribery, blackmail and coercion reduced the meagre income earned by these people. [4]

Moore and Rex (1967) observed that "The basic social processes within the city relate to the allocation of space, both through the market and by bureaucratic means, and to the resulting struggle over the urban space by different groups located at different points in the hierarchy of entitlements." For them, this is the class struggle over the distribution of life chances in the city in-comparison to struggle over city space. [5]

\section{Multivendor Marketplace}

It is an online marketplace where sellers or multiple vendors and buyers come together to initiate or to sell their products and conduct transactions, thus making profit with such an efficient marketplace model. Multivendor marketplace acts as digital medium that connects two participants of market i.e. sellers and buyers, thus making convenient shopping experience. Such Marketplace consists of three entities that are admin, vendors or hawkers and the customers.

\section{Existing System and Need for New System.}

The current system of hawkers and vendors consist of moving of hawkers from one place to another and covering different localities in order to find customers and sell their goods. It is based on physical interaction between customers and the hawkers/vendors. Since there is absence of a proper system of buying and selling, it causes congestion and traffic of hawkers at the same place. The need for a proper system is the need of the hour and that can be achieved by digitalizing the entire process and segregating hawking zones.

Application markets offer an interesting platform wherein software development can provide access to large number of potential customers and low marginal cost per user. However, these marketplaces are highly competitive due to the increasing number of online applications in the market. [6] In the study by $\mathrm{T}$. Tuomas the initial hypothesis was that these mobile application marketplaces offer street vendors reasonably profitable and easy way for developing country application vendors to sell and gain profit from their products by selling to a wide marketplace. According to the results of their study, they concluded that application vendors in middle or lower income countries create mobile applications generally because of the similar reasons of the application vendors in developed countries do. They lean towards mobile applications marketplaces since they offer simple access to huge measure of potential clients. Android system is preferred for its low improvement and access cost, but in any case, it is criticized for the wide scope of client interfaces. [7] 
Therefore we conclude that digitizing will prevent the hawkers from moving from one place to another without finding customers and also reduce the traffic jams and congestion caused by them drastically. Also, the customers can look for the required item available from different hawkers just by a tap on the phone and can order goods without any difficulty. The prices are more unified and there are available feedbacks of customers to look into. All these advantages and functionalities make us think about moving onto a new system as the world is going digital in every sector. This will contribute towards technological development in this area and its enormous possibilities to create value for the poor in the world

\section{MARKET SURVEY AND ANALYSIS}

There are various applications available on Google play store regarding online grocery shopping, food delivery and services.

For Example:

- Grofer's

- Big Basket

- Spencer's

- Nature's Basket

\begin{tabular}{|c|c|}
\hline & Features \\
\hline $\begin{array}{c}\text { Existing } \\
\text { Applications }\end{array}$ & $\begin{array}{c}\text { Provide deliveries of item } \\
\text { from retailers or dealers }\end{array}$ \\
\hline VENdiZ & Provide groceries from \\
street hawkers and \\
vendors.
\end{tabular}

Table 1: Comparison of existing apps with Vendiz

But none of these provide any means for customers to buy from local street vendors or hawkers. People from every society choose shopping from street hawkers and vendors. However, this market impacts our economy a lot as crores of turnover takes place every day from these unregistered vendors and hawkers. Therefore, a system upgradation is required that would solve these issues. Our proposed application would provide customer a better online shopping experience from their locality vendors and hawkers.

\section{Customer behaviour in buying products from local Street vendors and hawkers Vs Supermarkets}

In order to understand customer behaviour better in buying products from local hawkers, street vendors and supermarkets and to know their preferred medium we conducted a survey. Survey questionnaires were used to collect information regarding the customer's profile like gender and age and various other information that helps to know the factors that impacts the usage pattern of ecommerce based app services.
The responses from the respondents were tabulated and analysed to understand their usage pattern and behaviour.

\section{FINDINGS}

\begin{tabular}{|c|c|c|c|}
\hline Category & & $\begin{array}{l}\text { Numbe } \\
\mathbf{r}\end{array}$ & $\begin{array}{l}\text { Percentag } \\
\text { e }\end{array}$ \\
\hline \multirow[t]{3}{*}{ Gender } & Female & 36 & $39.6 \%$ \\
\hline & Male & 55 & $60.4 \%$ \\
\hline & TOTAL & 91 & $100 \%$ \\
\hline \multirow[t]{5}{*}{ Age } & Below18 & 8 & $8.8 \%$ \\
\hline & $18-30$ & 55 & $60.4 \%$ \\
\hline & $30-50$ & 17 & $18.7 \%$ \\
\hline & Above 50 & 11 & $12.1 \%$ \\
\hline & TOTAL & 91 & $100 \%$ \\
\hline \multirow{4}{*}{$\begin{array}{l}\text { Type of } \\
\text { Products } \\
\text { bought from } \\
\text { street } \\
\text { vendors }\end{array}$} & Fruits & 72 / 91 & $79.1 \%$ \\
\hline & Vegetables & 77 / 91 & $84.6 \%$ \\
\hline & Clothes & $9 / 91$ & $9.9 \%$ \\
\hline & $\begin{array}{l}\text { Household } \\
\text { items }\end{array}$ & $19 / 91$ & $20.9 \%$ \\
\hline \multirow{8}{*}{$\begin{array}{l}\text { Online } \\
\text { delivery } \\
\text { App } \\
\text { preference }\end{array}$} & Big Basket & 17 & $22.4 \%$ \\
\hline & Grofers & 10 & $13.2 \%$ \\
\hline & Spencer's & 2 & $2.6 \%$ \\
\hline & $\begin{array}{l}\text { Nature's } \\
\text { basket }\end{array}$ & 1 & $1.3 \%$ \\
\hline & Amazon & 41 & $53.9 \%$ \\
\hline & Flipkart & 2 & $2.6 \%$ \\
\hline & NONE & 3 & $3.9 \%$ \\
\hline & TOTAL & 76 & $100 \%$ \\
\hline
\end{tabular}

Table 2: Analysis

How often do you shop for daily groceries like fruits and vegetables? 91 responses

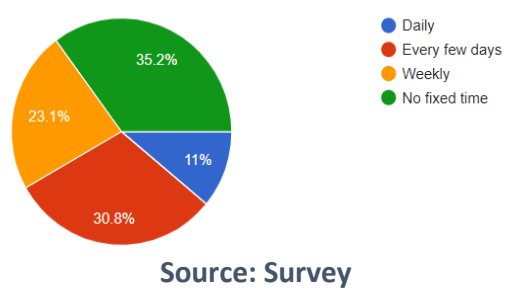

The results show that people do not have any specific time to buy groceries and buy them after every few days as required. 


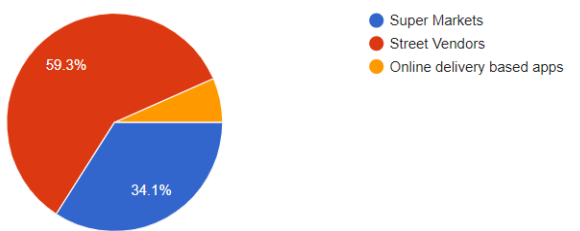

Source: Survey

The data analysis shows that the majority of the respondents prefer to shop for groceries from the street vendors $(59.3 \%)$ followed by Super markets $(34.1 \%)$ and a least of them prefer ecommerce $(6.6 \%)$.

\section{What affects your buying decisions?}

91 responses

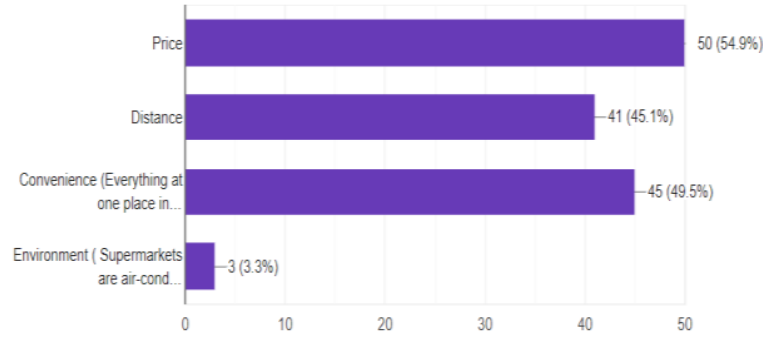

Source: Survey

According to the survey, the key factors that affect the buying decisions of customers are price of goods $(54.9 \%)$, Convenience $(49.5 \%)$, followed by distance $(45.1 \%)$ which indicates that customers prefer a reasonable price of goods at the convenience of their home.

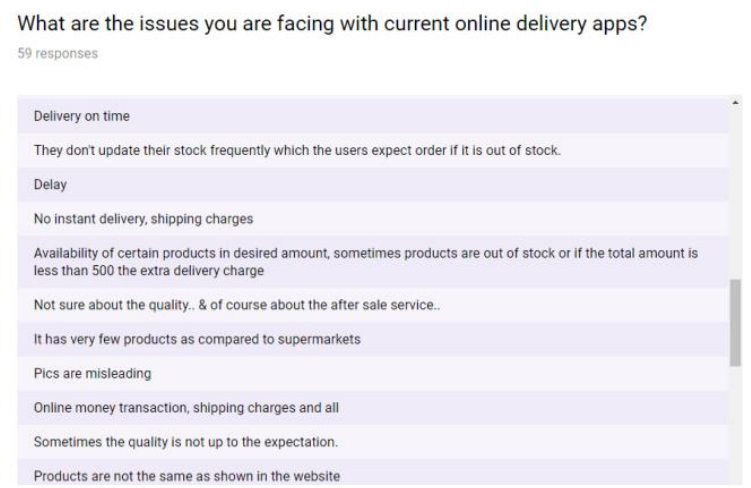

Source: Survey

The major issues that customers face from delivery apps were also recorded and some of the issues faced were delivery not on time, delay, misleading pictures, and quality mismatch. Would you like to use an app that connects you to your nearest street vendors for instant delivery? 91 responses

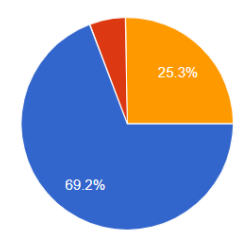

\section{Source: Survey}

Around $69.2 \%$ of the respondents are willing to use an app that can help them to connect to the local street vendors for instant delivery. $25.3 \%$ of respondents are not sure and $5 \%$ of respondents are satisfied with the current shopping experience.

The survey addresses the behaviour of customers towards buying products from local street vendors and supermarkets and the major findings from the survey are that customers prefer to buy products that are available instantly at their convenience at a reasonable price. The informal sector which includes the local vendors has a good potential in the market considering the above aspects of the findings from the survey conducted.

\section{PROPOSED APPLICATION - VENDIZ}

The objective of the project is to develop a web-based application which would facilitate direct interaction between customers and the hawkers/vendors via the app. Customers can navigate through the list of items available at different vendors and the prices at which they are offered by the nearest vendors and hawkers. Customers can then book the items and the hawkers or vendors can reach out to them instantly and deliver the same.

Some of the advantages of the application will be:

- Providing separate hawking zones for different vendors in order to reduce traffic.

- Add additional revenue for vendors

- Reduce their labour of moving from one place to another without sale by getting their item pre-booked via application.

- Provide licenses and give them legal status.

- Relief from extreme bargaining by customers.

- Customers can get their desired item instantly by just booking it via the app from the nearest vendors.

- Customers can review different vendors and compare their products and prices quickly.

Customers can navigate and find different local vendors present around their locality.

\section{Proposed Project's Description}

This application needs an android device which can be smartphones, tabs and other devices that usually have cellular or network connectivity. Some of the main features, functionalities and description of this android application are as follows

i. Registered users in this application have to login into their accounts by entering a username or user id and password if they are using it for the first. Afterwards they will remain logged into the application unless they log out explicitly. 
ii. If the user doesn't have an account on the application, they can register themselves on the main screen using the signup button.

iii. There will also be an option for resetting the password in case the user forgets his or her password. By clicking on the 'forgot password' button. The new password details will be sent to the registered mobile no. and

iv. Once the user signs in, he will be directed to the main screen of the application. This would be the main screen of the application, whenever the user will open the application this screen would appear. The user will be asked for the GPS location and after setting up GPS location, user can select category of the items he wants to shop for. The user can also select any other location manually.

v. The main screen or interface of the application would show different category of items sold by vendors and street hawkers with option of filter category as per needs of the user and also show user name and location.

vi. The user can search for the item he wants to buy manually using the search bar. After searching for a particular item a list of nearby street hawkers and vendor will appear. The app will also provide options for sort and filter search results.

vii. After selecting a particular vendor or hawker, another screen will appear showing vendor information like name, mobile no., category, rating, reviews, chat box, items to sell and their prices. User can message particular vendor for bargaining and placing order.

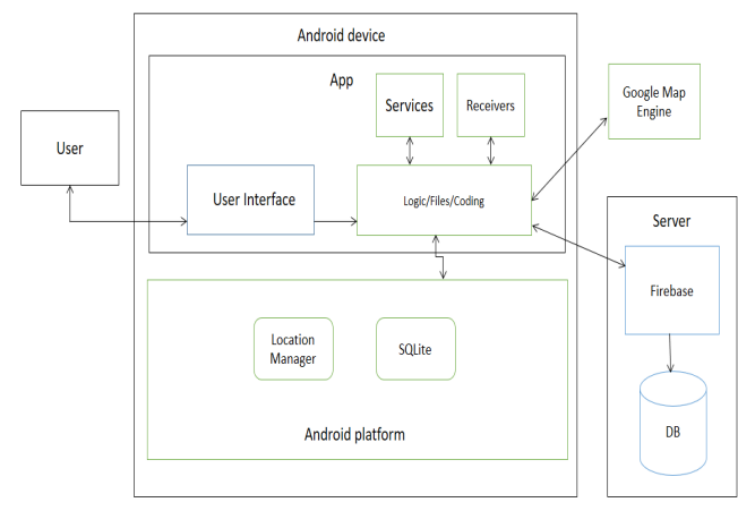

Figure 1. System Architecture of proposed application

The different components in the architecture are:

i. User: This is the target audience for whom the application is being developed. They are also called the end-users because they represent the actual audience who will use the real-world application.

ii. User interface: A UI represents the part of the application that is being displayed and is clearly visible while using the application. It is the visible window of the application which is used by the end-user. A simple and email id.

interactive user-interface is important to have a good user experience and product usability.

iii. Logic: These are the major part of the application which represent what will happen in the application and how different components of the application will interact with each other. It also uses different logics to fulfil the specifications of the application and contains major parts of backend code.

iv. Services: These are those tasks that cannot be seen through any user interface but run in the background in order to accomplish long tasks that require a long time to execute. Ex: tracking of location until the app runs.

v. Receivers: These are used to capture to actions that trigger any event in an application. They are typically event listeners which detect the activation of any event in the application.

vi. SQLite: It is an information repository or relational database that is used to store data relevant to the application. It is local particular to the device and has libraries available for developers in the Android. In our application it can be used to store the data related to the hawkers and vendors and their product list, contact or feedback information and location.

vii. Location Manager: It is basically used to provide the location of the device that will be used by the street hawkers and vendors. It can use both GPS and mobile network connectivity based on the requirements of the location tracking.

viii. Google Maps Engine: The application uses Google Maps in order to provide the location of the street hawkers and vendors by using an Android API v2 to work along with the maps and fetching location. Various calls can be made to the API to use the map and therefore track the nearby vendors and hawkers.

ix. Database: This is the main information repository or database that is used on the server side in order to store, process and manipulate data permanently for the application. It stores the information that details about the different street vendors and hawker, their personal information and contact information, goods they sell along with the prices, the feedback for each hawker and also the location they usually operate from.

x. Firebase: Firebase is an API provided by Google that provides real-time database management system in cross-platform and web applications. It stores data on its cloud and provides authentication and security. Firebase analytics can also be used to gain useful insights on the usage of the application and the overall engagement of the users of the application. 


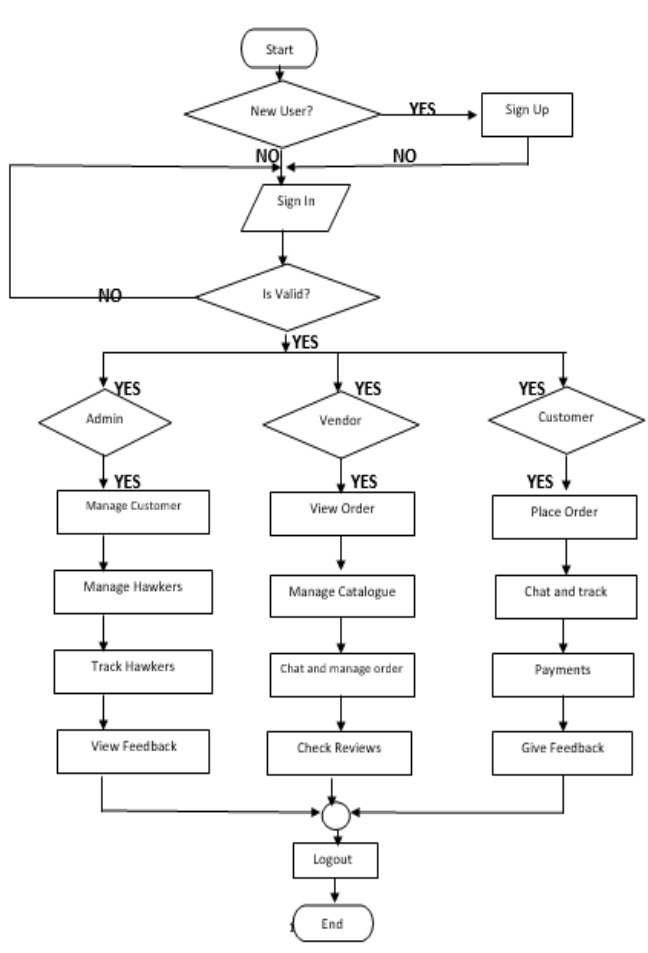

Figure 2. System Flowchart

\section{USER PANEI}

\section{USER INTERFACE}

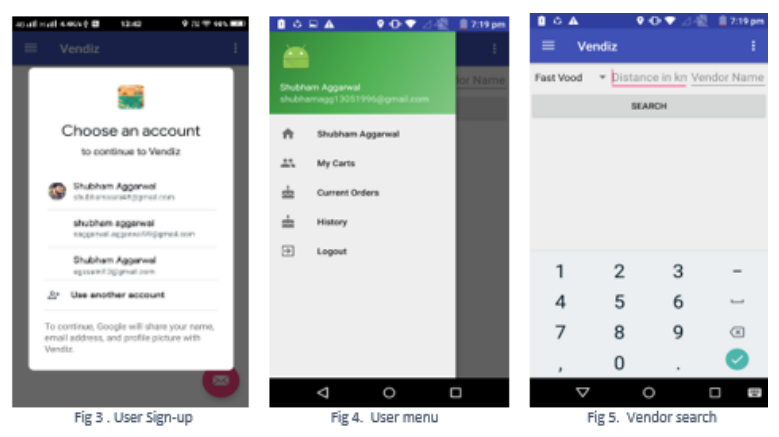

2.. ADMIN PANEL

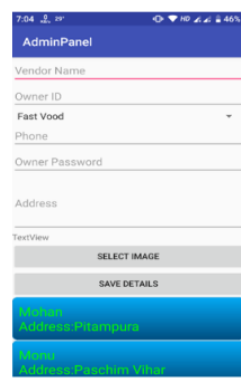

Fig 9. Vendor Registration

\section{VENDOR PANEL}

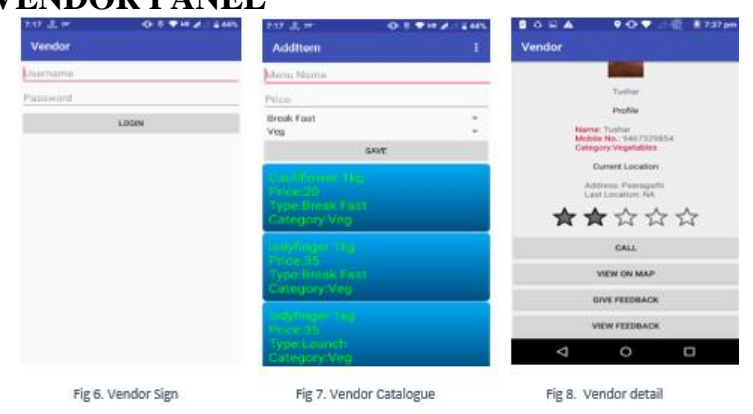

\section{CONCLUSION}

This study addresses the problems faced by local vendors and hawkers who sell their goods and face difficulties in generating adequate revenue and our application is intended to target the local vendors who can get connected to a much higher potential of customers nearest to them and reduce effort to sell their goods. The customers can get instant products within minutes after connecting to the nearest local vendors and get the items as and when they require. Our application intends to address a social problem as well as show the market opportunity available that can be capitalized with the right business strategy and execution. We also have a scope of further research and better implementation of our application with adding new features that can make it more attractive and serve a higher number of people.

\section{A. References}

[1] Sharit K. Bhowmik and Debdulal Saha, "Street Vending in Ten Cities in India" For

National Association of Street Vendors of India, Delhi, June 2012

[2] M. Suresh, George J., "Study of the Lighting Sources of Street Vendors in Kerala and Their Willingness to Switch to Solar Lanterns."

[3] Prof. Dr. Arvind Chaudhari "Changing paradox of street vendors and vendor zones in India", Volume 5, Issue 12, December (2014), pp. 90-98, International journal of management.

[4] S.K.Bhowmik, "Street Vendors in Asia: A review," Economic and political weekly, 2005.

[5] R N Sharma "Politics of urban space".

[6] Holzer, A. \& J. Ondrus. "Mobile application market: A developer's perspective." Telematics and Informatics, 2011, 28: 22-31.

[7] Tuomas Tanskanen, Anne-Marie Tuikka, Sami Hyrynsalmi, Kai K. Kimppa, "The Potential Development Impact of Mobile Application Vendors in Developing Countries". 2015 IEEE International Symposium on Technology in Society (ISTAS)

[8] Sharit K. Bhowmik., "Urban Responses to Street Trading: India", Hawkers in the Urban Informal Sector: A study of street vendors in six cities, National Alliance of Street Vendors of India.

[9] B. Balasubramanian, Dr. R. Srinivasan, Dr.S. Vaidhyasubramaniam," Women in Informal Sector: A case of Women Street Vendors in Thanjavur, Tamil Nadu", 2012 (ICMIEE).

[10] Nasibu Mramba, Professor Erkki Sutinen, Dr. Michael Haule, Dr. Peter Msami" Survey of mobile phone usage patterns among street vendors in dar es salaam city-Tanzania", ISSN 2304-0777, Vol.28 No.1, International Journal of Information Technology and Business Management

[11] Nasibu Mramba, Mikko Apiola, Erkki Sutinen, Michael Haule, Tina Klomsri, and Peter "Empowering Street Vendors through Technology: An Explorative Study in Dar es Salaam, Tanzania".

[12] Keerthana S. and Suresh M. "Drivers Influencing Lean Practices in Street Food Vending Process", 978-1-5090-0612-0/16/\$31.00 (O2016IEEE. 